\begin{tabular}{c||l} 
& $\mid \begin{array}{l}\text { Castern } \\
\text { Curopean } \\
\text { Countryside }\end{array}$ \\
\hline DOI: 10.2478/v10130-009-0005-5 & $15 ’ 2009$ \\
Lynette Šikić-Mićanović &
\end{tabular}

\title{
Women's Contribution to Rural Development in Croatia: Roles, Participation and Obstacles
}

\begin{abstract}
Unequal access to formal employment, decision-making power and social prestige can lead to vulnerabilities and social exclusion especially in rural areas. Feminist researchers and advocates for women assert that the preservation of agriculture, family farming and diverse rural culture in particular depend on the empowerment and participation of women (Hoff 1992, p. 79). In this paper, I attempt to evaluate rural/farm women's position and the extent of their vulnerability and social exclusion in an area of Slavonia in the eastern part of Croatia. Specifically, I use interview and fieldwork data to identify and elaborate their roles, participation in decision-making, and the obstacles/ constraints that rural women face in these rural communities to evaluate the extent of their contribution to rural development. Further, it is my intention to explore if rural women represent an untapped resource in rural spaces that would contribute to rural development and raise the quality of life in these areas.
\end{abstract}

Keywords: rural women, development, roles, participation, obstacles

\section{Introduction}

Feminist rural scientists have documented how women's contribution to the development of rural areas is hindered by their lack of access to land, credit, education and training, knowledge and decision-making (Alston 1995a; Sachs 1996; Shortall 1999; Whatmore 1991). In addition, scholars have also referred to the male hegemony of rural society and the dominance of rural 
ideologies which emphasise women's domestic and family roles (Little and Austin 1996). Inevitably, a pervading male hegemony in rural communities invariably shapes women's lives as a determinant of women's social position (Poiner 1990) rendering them and their work invisible, undervalued, and unrecognised (Alston 1995b; Sachs 1983; Whatmore 1994; Williams 1992). Thus, traditional and conservative practices as well as attitudes about gender make participation in public spheres problematic for women. This is not only internalised by women to restrict their participation in rural life, but they are likely to be judged and criticised by both women and men for breaking the accepted codes of behaviour within the rural community (Hughes 1997). It has also been claimed that many rural women feel either that feminism is irrelevant to them, or that their frank acknowledgement of a feminist agenda would damage their position in rural communities (Teather 1998, p. 212). Thus, since women's subordination under the predominant male hegemony denies them any public power, they fear their loss of private power which they see as a very real possibility under feminism (Alston 1995a; Teather and Franklin 1994). Overall, research on women's position in rural development initiatives has focused on cultural and traditional factors, rather than biological differences between men and women to account for differences in rates of participation (Clark 1997; Little and Austin 1996). For example, Claridge (1998, p. 185) shows that the constraints and barriers experienced by women that limit their participation, especially in decision making and leadership fall into three categories: socialised, situational and structural. Socialised constraints include the socialisation process itself as well as sex stereotypes, self-confidence, undervaluing women's role, and different gender styles of operation. Situational constraints relate more to the circumstances under which women operate - for example time and family commitments - while structural constraints result from organisational structure, which originates from socialisation. Likewise, in her study, Pini (2002) concluded that there are five main factors which constrain women's involvement in agri-politics. These are a lack of support, the conduct, time and location of meetings, the masculinist culture of the organisation, women's multiple commitments and lack of interest. Similarly, Grace (1997) in her work specifically on barriers to women's participation identified structural and cultural barriers such as the hierarchical nature of the organisations, the inconvenient meeting times and the lack of childcare as well as the 'old boy' cultures and sexual harassment. There have been several careful studies on the way that women who want to 'buck the trend', challenge the norms, have been ostracised and even driven 
out (Middleton 1986). It is difficult for those who want to be different as they become very noticeable and a topic of gossip in small scale communities that have more power over the individual and are able to bind the individual strongly to the will of the community (see Arnett 1995).

In sum, women's contribution to rural development is often hindered by their lack of capital (e.g. economic and cultural) and dominant rural ideologies that not only determine rural women's roles and position but in turn present obstacles to women who want to fully participate in the public sphere. Conversely, it is often overlooked that the overall development of rural areas is essential for the viability and sustainability of a country as it is the base of a country's economic and social condition. At present, Croatia is facing the huge task of revitalisation, reconstruction and recomposition (diversification) of its rural communities and areas (Štambuk, Rogić and Mišetić 2002, p. 380). The extent of this task depends on the region and on the village's degree of heterogeneity, social and economic structures, local culture as well as different reactions to transition and globalisation (Serefagić 2002). In any case, this is an enormous undertaking because the surface of rural areas in Croatia is 91.6\% and the number of settlements is 6,001 according to OECD criterion (CEEC Agri Policy 2006) ${ }^{1}$. A number of recent studies have focused on the revitalisation or renewal of rural villages (or reasons for their disappearance or decomposition Kušen 2003) as well as the quality of life in rural areas in Croatia (Štambuk and Rogić 2001; Štambuk et al 2002). Recommendations include: the improvement of social and economic development (Karaman-Aksentijević, Denona and Grčić 2000); the potential of natural and local resources (Lay 2002; Cavrak 2003); the development of traditional heritage and rural tourism (Kušen 1998; Magaš and Smolčić-Jurdana 1998); and rural diversification (Njegac and Toskić 1998). However, very few have paid specific attention to rural women's role in the development of Croatian rural areas (although there are exceptions: see Žutinić 2003a; Ilak Peršurić 2003) or their contributions to the quality of rural life and the importance of these responsibilities to overall rural development. In response to this gap, this paper is a preliminary attempt to investigate the equality of opportunity (involvement of women in spheres of employment, enterprise, education, training, as well as the reconciliation of professional and family life) in a rural area of Croatia.

${ }^{1}$ According to EU criteria the surface of rural areas is $84.6 \%$ while the number of settlements is 5,318 (CEEC Agri Policy 2006). 


\section{Historical Background of Rural Populations in Croatia}

After WWII, Croatia experienced rapid economic changes transforming it from a peasant society to an industrial one. The development of industry, especially heavy industry was envisaged in Croatia following socialist aspirations, to deal with an 'overlarge' rural population ( $76 \%$ in 1953 compared to $46 \%$ in 1991). Men predominantly took part in the initial mass migrations from villages into cities while the women stayed back in the villages to resume farm work (Rihtman-Auguštin 1985, p. 41). According to Štambuk (2003), besides the stigma of being the 'socio-political enemy' if they resisted this enforced political and economic framework, rural people were also stereotyped as being backward and provincial. At the bottom of the social scale, they were subjected to exceptionally unfavourable conditions for which they were totally unprepared. Along with strong de-agrarisation pressure imposed by the State, rural spaces became unimportant and undeveloped while rural inhabitants were demoted and devalued. Unfortunately, the stigmatisation of rural spaces remains today; popular discourses still contextualise rural space as 'unpromising' and 'poor' compared to urban spaces that are 'promising' and 'good'. Incontestably, as a consequence of transition and war, rural areas were further disadvantaged. In other words, in more recent times they have become 'zones of exclusion' as a result of depopulation ${ }^{3}$ (especially the young and skilled), aging populations ${ }^{4}$ and overall economic decline (Brkić and Žutinić 2001, Štambuk et. al. 2002; Petak 2002; Pejnović 2004). Undisputedly,

2 This is in striking contrast to popular discourses of the rural (e.g. in the UK) that rely on imagery that present the countryside as places where happy, healthy stress-free lifestyles are lived where people can enjoy the benefits of trouble free events, away from the stresses and uncertainties of the urban mayhem (see Matthews Taylor, Sherwood, Tucker and Limb 2000). Other authors have suggested that the rural idyll has both aesthetic and moral components where people can enjoy an innocent and harmonious existence away from the moral corruption of city life (Share 1995).

3 According to Pokos (2002) 85\% of all rural villages in Croatia were depopulated between $1953-2001$ and $45 \%$ of these villages were reduced by more than $50 \%$.

${ }^{4}$ The age index (the analytical index of the population age structure expressed as the relationship between the young and the old populations) for rural populations in the last decade has increased from 0.79 to 0.96 . The population is considered as old if it exceeds 0.40 , which has a further impact on a community's ability to reproduce and its overall viability. Moreover, there is a much lower proportion of women of reproductive age (between 18-49 years of age) in the total population of rural areas compared with urban areas in Croatia. 
transition and war also strengthened patriarchal and nationalist attitudes that subsequently worsened and marginalised women's position. Leinert-Novosel (2000, p. 7) identifies a number of transitional effects, which primarily have had an impact on the position of women in Croatia. These include: job loss, longer periods of unemployment, a decrease in financial family support, a lower standard of living, a growth of domestic violence, as well as the disappearance of women from the higher levels of political power. Clearly, women have experienced these macro/micro-level changes differently than men and have been differentially affected by them since economic and political processes are not gender neutral (Gal and Kligman 2000). In all probability, rural women bore the brunt of this devastating social and economic situation and became a particularly 'vulnerable' social group because of their low levels of capital (economic, cultural, social and symbolic) and their family obligations (Leinert-Novosel 1999; 2000; Tomić-Koludrović and Kunac 1999; 2000). Unfortunately, this gendered lag continues as an analysis of educational structure shows a number of negative developments characterising the situation in the rural areas of Croatia. Based on statistics from the latest census $(2001)^{5}$ girls more frequently $(29.9 \%)$ start but do not finish primary school compared to boys (18.6\%) in Croatian rural areas and females are less successful at finishing secondary school (only 31.1\%) compared to almost half the male rural population (48.5\%). In addition, a higher number of rural women $(55,168$ or $6.6 \%)$ have never been to school compared to rural men (1.9\%). Furthermore, the risk of poverty is particularly high when low levels of education are combined with unemployment. Beyond doubt, Croatia and its rural population throughout history have endured a number of different changes that have created new opportunities but also produced setbacks that have added to the vulnerability of those who are unable to adapt ${ }^{6}$.

The vulnerability and social exclusion of rural/farm women in a rural area of Croatia and the repercussions of this on rural development are of particular interest in this paper. To reiterate, this preliminary examination attempts to show the extent of women's contribution to rural development by identifying and explaining their multifaceted roles in rural villages, their participation in

5 These figures were calculated by Đ. Žutunić (2003b) since the last census did not differentiate rural and urban settlements.

${ }^{6}$ These changes include: restructuring of the labour market in response to rapid economic change and globalisation; rapid growth of the knowledge-based society and of information and communication technologies (ICT); an ageing population and higher dependency ratios; and continuing changes in household structures (Bejaković and Kaliterna Lipovčan 2007). 
decision-making at the public level, as well as the obstacles/constraints that women face in rural communities. Further, it is my intention to explore if rural women represent an untapped resource in rural spaces that could be used, developed and used in the formal economy.

\section{Research Field and Method}

Fieldwork for this study was conducted in rural villages in the VukovarSirmium County ${ }^{7}$, one of the 21 counties in the Republic of Croatia that was established in 1993, following Croatia's independence, with Vukovar as its main administrative centre. The county is situated at the very north-east of Croatia, covering an area of $2,454 \mathrm{~km}^{2}$ between the rivers Danube and Sava, and comprises the historic regions of Eastern Slavonia and Western Syrmia. In contrast to migratory patterns in the past ${ }^{8}$, statistics (CBS 2001) indicate that more people emigrated from rather than immigrated to this county (with a migration balance of -281). The latest figures indicate that the total population in this county decreased to 204,768 (from 231,241 in 1991), and that there are nearly 8,000 more women [males 98,470 (48.1\%); females 106,298 (51.9\%)]. The lengthy military occupation (until 1998) slowed down processes of reconstruction that were of urgent need since this county suffered the most tragic consequences and heavy losses ${ }^{9}$. Research for this study involved structured questionnaires for demographic details and open in-depth interviews designed to explore a variety of gender issues (on their gendered roles in domestic labour and the rural economy, participation in decisionmaking, and the obstacles that they face as well as their life experiences and personal life choices and aspirations, etc.). Although the original sample was much larger, I selected a sub-group of women for interviews (43 married

7 These include: Gunja (popn. 5,033), Bošnjaci (popn. 4,653), Drenovci (popn. 3,049), Posavski Podgajci (popn. 1,568), Rajevo Selo (popn. 1,407) and Račinovci (popn. 982).

${ }^{8}$ From the $19^{\text {th }}$ until mid $20^{\text {th }}$ century, Catholic Croatians from other regions (e.g. Gorski Kotar, Lika, Dalmatia, Zagorje, Bosnia and Herzegovina) migrated to this county for economic reasons. As a large part of this county's area (62\%) was cultivable land and century-old forests, particularly oak constituted a great part (28\%), people were drawn to the natural heritage of this region to avoid starvation.

9 For comparative purposes, the GDP per capita in the richest county of Croatia, the City of Zagreb, amounted to HRK 71,111 (about €9,605), which was more than three times greater than GDP per capita in the county of Vukovar-Sirmium (the poorest), where it averaged HRK 23,400 (around €3,160) in 2002 (Bejaković and Kaliterna Lipovčan 2007, 14). 
women with children). This research also included the time I spent with village women in less structured settings which helped me understand more about their experiences and lives, for example helping women with their household chores or preparation and participation in community events such as feast days and rites of passage.

\section{Exploration of Women's Roles in Rural Areas}

Rural women are not a homogeneous group; they have different roles and occupations, employment, community activities, different interests and needs depending on their age group, and family size/composition. Nevertheless, in this study, all rural/farm women have something in common: they all have multiple roles and often have the 'longest' working day as they play a major role in the survival strategies and economy of rural households. Firstly, they spend significantly greater amounts of time on unpaid domestic labour than men; they undertake the bulk of housework duties, childcare and other 'invisible' tasks that are a crucial part of domestic work ${ }^{10}$. These 'invisible' tasks include: emotional work, care work, kin work, household management work and status enhancement work. This social reproduction occurs mainly in the home and includes all the work required to provide for the health and well-being of families. Hence, beyond providing for the family's physical maintenance, this work also supports the emotional and psychological well-being of both individuals and the family collectively that in turn is reproduced at community level. Unfortunately, this domestic work is not counted as real or vital for the economy in Croatia, even though it is just as important for the maintenance of society as the productive work that occurs in the formal market economy. They also contribute to the family's economic well-being by being thrifty in the home, by making and repairing clothing as well as home décor, and by growing and preserving their own fruit and vegetables, which is all a part of 'being a woman' in these communities. Secondly, many of these women work in the informal economy (handiwork, selling their produce at the market, cleaning, catering for weddings, feast days, etc.) to make ends meet which enables them to structure their day around their family's schedule. As their 'paid' economic activities are predominately in the informal sector, they are often low-paid,

${ }^{10}$ Apart from their resourcefulness, women are expected to be versatile in these rural areas. They also need to know how to do men's (farm) work in their absence although men are not expected to do women's domestic work. 
low-status, temporary, and casual with less economic and symbolic power ${ }^{11}$. One of the crucial research questions that emerged during this study was: Why do women make these choices to do unpaid domestic labour and 'paid' informal work which offers no social protection, professional status, rights or benefits? Why do they make these life choices to the detriment of their own personal and professional development that effectively increases their vulnerability and social exclusion? Much of their work is seasonal, at home, low-risk, economical and flexible so that they can meet the needs of others in their family. Women explained to me that work of this nature is preferable as women are able to reconcile their childcare/domestic work with their paid 'informal' work which is consistent with notions of being a 'good' wife and mother ('doing femininity') in these rural communities. Unsurprisingly, only a sixth of the women in this sample are formally employed and research results show that this low workforce participation can be attributed to their traditional upbringing and prospects, level of education, limited paid-work opportunities as well as the paucity of childcare facilities in these rural areas ${ }^{12}$.

\section{Women's Participation in Decision-making}

Women are more or less excluded from 'male-dominated' formal network groups (e.g. sport, agricultural cooperatives and political parties) but the Catholic Church and the folklore group KUD offer women in these rural spaces opportunities for building up social capital and in some cases decision-making in the public sphere. 'Going to church' is one of the few public/social activities that exist and are suitable for women in these villages. Their religious activity gives women a legitimate place in the public sphere which otherwise is to some

11 Encouragingly, taking into consideration the special circumstances that rural women face as well as appreciating their contribution to the economic survival of their families, the Ministry of Agriculture and Forestry in the Republic of Croatia has been attempting to raise awareness of women's multifaceted role in rural areas. For example, the Croatian Institute for Agricultural Advisory Service has been specifically working on the improvement of living conditions of women in rural areas since 1998. Through this programme, networks of rural counsellors directly work with rural women to raise awareness in rural communities of their roles for the development of agriculture as well as rural areas.

${ }^{12}$ Kindergartens have never been part of a village's infrastructure in this region, although some of the villages where I conducted my fieldwork are quite large with populations that range between 1,000 and 5,000. The closest kindergarten is approximately 30 kilometres away. 
extent blocked from them. Although women are well represented (almost equally) in the local church councils, they are largely responsible for many of the non-sacred aspects (food preparation, church cleaning, decorating, etc) of religious activity. Evidently, in this way they 'fill in gaps' since these activities are an extension of their 'domestic' roles and thus complementary to, a system in which the church hierarchy is male and the formal prescribed rituals in the church are carried out by men. Women are also actively involved in the folklore group KUD which organises different activities such as traditional folk music, dancing, singing and handiwork. They usually become lifelong members as young girls but rarely join as married/widowed women as this would conjure up gossip in the community. In these groups, women often carry out the manual tasks necessary for the coordination of events in these networks where entry is encouraged and supported by the community but they are usually (with few exceptions) not represented in the decision-making processes nor do they have access to the benefits that accumulate there. As there are no women's associations in these rural areas ${ }^{13}$, women's interests are not well represented and their overall low level of participation in decision-making at the local level inevitably leads to biases in rural development programmes and policy in Croatia.

\section{Obstacles to Equal Opportunity}

There are a number of obstacles that rural women face preventing them from becoming fully involved in the communities they live in. Research indicated that there is: a) almost no balance in the gendered division of domestic labour-this is strictly women's work ${ }^{14}$; b) a total absence of quality care services in these villages (childcare, elderly); c) a definite lack of quality of support services (self-employment, entrepreneurship); d) an absence of

${ }^{13}$ In Croatia, about fifty women NGOs are active and are a part of the Women's Network Croatia that unites organisations, groups and initiatives that recognise discrimination against women who are often economically and politically marginalised. In addition, there are some organisations that promote business and self-employment in rural areas (e.g., Lobi that focuses on the development and organisation of the local community). None of these services or forms of support is available to women in the County of Vukovar-Sirmium, except for one located in Vukovar - a two hour drive from any of these villages where I conducted my fieldwork.

${ }_{14}$ As a rule, men do not do this work. Although there is a higher probability that men will 'help out' rather than share these duties and responsibilities especially if they grew up with their mothers, now live in nuclear households and work in another city or abroad. 
a reliable affordable transport network ${ }^{15}$; and e) a near non-existence of leisure activities/entertainment and internet services in these rural communities. All these factors play a large part in sustaining rural communities. Rural women, in particular, are disadvantaged because they often have to perform the domestic labour (housework, childcare, elderly) as well as 'patch up' the household budget, which often leaves them with little time for anything else (e.g. if they desire to start their own business, travel around, engage in leisure activities or access information from the internet).

As rural women have very limited ways of reconciling family-work obligations in the absence of care and support services (as well as jobs in the formal economy), they often choose to put their families first. Being 'married' and a 'mother/homemaker' are seen as the central facets of women's identities, while education and having a career are less important to a woman's social identity in these rural areas. This is clearly apparent in their formal education and employment records. Over half of the women (56\%) in this sample only finished some grade of primary school, most commonly a lower grade while two never attended school. Few (29\%) only finished secondary school. Fewer women (15\%) completed some level of tertiary education. Subsequently, employment opportunities are further limited by their inadequate educational qualifications. Another problem is that information that may be useful to women (e.g. funding for professional education for alternative types of employment and self-employment provided by the Croatian Employment Bureau) is not available to them unless they have internet access. In any case, adult education programmes are insufficiently developed in rural areas while there are poorer opportunities for additional training and advanced studies for unemployed persons. Besides limited access to funding, less experience as well as less contact with support networks, women are further inhibited by prevalent social norms and marginalised by dominant rural culture values. For example, two women in their 40s attempted to run their own cake business but could not endure the gossip and criticism that their encroachment awakened in the community. Eventually they had to abandon the whole venture because their entrepreneurial activity had begun to threaten their husbands' standing

15 This severely debilitates women's movement as most of the women (78\%) in this sample do not a have a driving licence. In some instances, in seemingly asymmetrical marital relationships, husbands do not allow their wives to get a driving licence (as long as he can drive) because 'she is a woman and this is something men do best' so this becomes a social restriction on mobility. 
in the community. In other words, they were disgracing and discrediting their husbands who had to pull more weight at home to reconcile their wives' new work commitments. This was socially unacceptable and risky behaviour because they had no financial or emotional support even though they were doing a typically 'woman's job' - baking cakes.

\section{Rural Women - Untapped Resource?}

The weaknesses of the socio-economic context, administration as well as human potential in rural areas outlined in the beginning of this article give the impression that the situation in rural areas is bleak, hopeless and unpromising. However, researchers working in other countries have found that women play a pivotal role in rural development because they can find alternative solutions and mobilise different resources (Bock 2003, Hoff 1992) to maintain and rebuild rural communities. Research in Croatia among rural women has shown that women mainly focus on social needs (Žutinić 1994), which would be highly advantageous in terms of rural development. There is no doubt that rural women substantially contribute to the health and wellbeing of their families as well as the wider community. Research results from this study show that rural women are versatile, resourceful and possess a range of special aptitudes and skills that can be developed and used in the formal economy. This could be in new sectors that have development potential (i.e. local services, agro-food industries, tourism, home-working, leisure facilities and the environment) because women may have an advantage in that they often have an awareness and knowledge of local needs and have special interpersonal and communication skills. In addition, many of these sectors of economic activity involve seasonal work and represent a continuation of women's reproductive work that is socially acceptable gendered work for women in these rural communities. In any case, it is important to address gendered needs, concerns, desires and aspirations because creating a social and community framework that meets these expectations is an integral part of effective rural development.

\section{Concluding Remarks}

Although this study by no means represents the diversity of rural/farm women in Croatia, much insight can be gained from this study on their experiences, concerns and perceptions. It is beyond doubt that rural women in this study 
not only contribute considerably to the survival of their household but also to the viability of the rural economy. However, since their work is often 'invisible' and unpaid it is not recognised for what it is worth. Predictably, in a patriarchal rural culture, girls from a young age are encouraged to learn skills that help them prepare for married life and motherhood. Subsequently, rural women in Croatia tend to have lower educational levels, lower employment rates and an overall lower participation in the public sphere. Nevertheless, they find alternative ways of accessing social support that contributes to their wellbeing and gives rural communities a special quality of security, familiarity and openness. To make their lives more manageable, they maintain close emotional relationships with their kin and neighbours to get help when needed. This assistance includes child care, financial aid and help with transportation that considerably increases their sense of belonging and emotional well-being. For instance, informal child care arrangements often give women more time and flexibility and less anxiety about their children's safety. Thus, this social support often provides them with social capital to buffer them against their life challenges and to devise new strategies to diminish their vulnerabilities. Nevertheless, research results from this study indicate that women's abilities and capacities need to be recognised and not exploited or neglected as a way of reducing poverty, enhancing economic growth and well-being. If they are 'worn out' and can no longer cope with all their responsibilities (as well as those towards themselves) this will have a detrimental affect on the health and survival of the entire community. It should also be noted that rural women in this study have to frame their own preferences and aspirations within a sociocultural context in which there are limited opportunities for them to develop. Women who do not conform to these social norms and expectations risk being marginalised by the dominant rural culture. For this reason, public institutions in their policy-making have the demanding task of understanding life as an individual gendered experience rather than a collective one. Moreover, by quantifying the importance of different types of work carried out in rural areas and by eradicating the barriers, the visibility of those who are invisible can be raised in rural policy. In any case, activities related to professional orientation, lifelong learning, education and qualification, and professional development ought to be enhanced in rural communities. Women, in particular should be encouraged and supported to pursue development opportunities on the same footing as men. By expanding rural women's abilities a substantial contribution to the quality of life for all can be achieved. This is necessary for the viability and sustainability of rural development and its integration is an obligation in 
Croatia. Undoubtedly, through the participation and contribution of women, the social fabric of rural communities is maintained and rural economies are revitalised. Fundamentally, it is necessary to pay attention to the conditions, situations and needs of men and women and also to address gender disparities (gaps/differences) and inequalities that were and are barriers to rural development.

\section{References}

Alston, M., Women on the land. Sydney 1995a: University of New South Wales Press. Alston, M. (1995b), 'Women and their Work on Australian Farms', Rural Sociology, no 60(3), pp. 521-532.

Arnett, J.J., 'Broad and narrow socialisation: the family in the context of a cultural theory', Journal of Marriage and the Family, no 57, 1995, 617-628.

Bejaković, P. and Kaliterna Lipovčan, L., 'Quality of life in Croatia 2007: Key findings from national research', http://www.eurofound.europa.eu/publications/htmlfiles/ ef0729.htm.

Bock, B., Combining everything at the same time: Dutch farm women as rural entrepreneurs, in: A. Ilak-Peršurić (ed.), Women's perspectives in family farming and rural development, Poreč 2003: Institute for Agriculture and Tourism, pp. 1-13.

Brkić, S. and Žutinić, Đ., 'Education of rural youth as the factor of exodus or professionalisation of farming, Eastern European Countryside, no 7, Torun 2001: UMK, pp. 101-115.

Cavrak, V., 'Održivi razvoj ruralnih područja Hrvatske' ['Sustainable development of Croatian rural areas'], Zbornik Ekonomskog fakulteta u Zagrebu, no 1(1), 2003, pp. 61-77.

Claridge, C.L., 'Rural women, decision making and leadership within environmental and landcare groups', Rural Society, no 8 (3), 1998, pp.183-196.

Clark, G., Rural Women: Gender relations and socio-economic change, Rural Forum Scotland Policy Briefing Document Edinburgh 1997: Rural Forum.

CBS (1991) Census Reports. Statistical Yearbook of the Republic of Croatia. Central Bureau of Statistics, Zagreb 2001. www.dzs.hr.

CEEC AGRI POLICY, 'Agro-economic policy analysis of the new member states, the candidate states and the countries of the western Balkans'. Project no 513705 Rural employment in the context of rural development in Croatia, 2006.

Ilak Peršurić, A., Women's perspectives in family farming - between housewives and managers, in: A. Ilak-Peršurić (ed.), Women's perspectives in family farming and rural development Poreč 2003: Institute for Agriculture and Tourism, pp. 30-39. 
Gal, S. and Kligman, G. (eds.), Reproducing Gender: Politics, Publics and Everyday Life after Socialism, New Jersey 2000: Princeton University Press.

Grace, M., Networking Systems for Rural Women, Canberra Rural Industries Research and Development Corporation, 1997.

Hoff, M.D., 'Women's Perspectives in the Rural Crisis and Priorities for Rural development., Affilia, no 7 (4), 1992, pp. 65-68.

Hughes, A., Rurality and cultures of womanhood, in: P. Cloke and J. Little (eds.), Contested Countryside Cultures: Otherness, Marginalisation and Rurality, London 1997: Routledge, pp. 123-137.

Karaman-Aksentijević, N., Denona, N. and Grčić, B., 'The Possibilities for the Improvement of the Quality of Life in Croatian rural areas', Naše gospodarstvo, Revija za aktualna gospodarska vprašanja, no 46 (1), 2000, pp. 113-125.

Kušen, E., 'The Saborsko Project: A model project for the development of rural tourism in a war-affected region', Tourism, no 46 (2), 1998, pp. 75-102.

Kušen, E., 'Uređenje, razvoj i obnova hrvatskog ruralnog prostora: Prostorni, gospodarski i sociokulturni okvir za razvoj ekološke poljoprivrede' ['Readaption, development and renewal of Croatia's rural areas. Spatial, economic and socio-cultural frame for ecological agricultural development'], Sociologija sela no 41 (1-2), 2003, pp. 29-45.

Lay, V., Prilozi osmišljavanju usmjeravanja razvitka ruralnih prostora hrvatske na osnovama ekološke I gospodarske održivosti [Contributions to make meaningful the development of rural spaces in Croatia on the basis of ecological and economic sustainability], in: M. Štambuk,. I. Rogić and A. Mišetić (eds.), Prostor Iza: Kako modernizacija mijenja hrvatsko selo. [The Space Behind: How Modernisation has Changed the Croatian Village Anthology no. 17], Zagreb 2002: Institute of Social Sciences, Ivo Pilar.

Leinert-Novosel, S., Žena na pragu 21. stoljeća. Između majčinstva i profesije. [Women at the Turn of the $21^{\text {st }}$ Century. Between Motherhood and Professions], Zagreb 1999: Ženska grupa TOD.

Leinert-Novosel, S., Democratic Transition and Position of Women in Croatia, in: J.A. Petrović (ed.), Diskriminacija žena u Hrvatskoj [The Discrimination of Women in Croatia] ICFTU CEE Women's Network Ženska sekcija SSSH, 2000. Little, J. and Austin P., 'Women and the Rural Idyll', Journal of Rural Studies, no 12, 1996, pp. 101-111.

Magaš, D. and Smolčić-Jurdana, D., 'Development of tourism in rural areas of Croatia, Rural tourism management: Conference proceedings. Rural Tourism Management: Sustainable Options', Scotland 1998: SAC Auchincruive, Ayr, pp. 53-60. Matthews, H., Taylor, M., Sherwood, K., Tucker, F. and Limb, M., 'Growing Up in the Countryside: Children and the Rural Idyll', Journal of Rural Studies, no 16, 2000, pp. 141-153. 
Middleton, A., Marking boundaries: Men's space and women's space in a Yorkshire village, in: P. Lowe and T. Bradley (eds.), Deprivation and Welfare in Rural Areas, Norwich 1986: Geo Books.

Njegac, D. and Toskić, A., 'Rural diversification and socio-economic transformation in Croatia, GeoJournal, no 46 (1), 1998, pp. 263-269.

Pejnovic, D., 'Depopulacija županija i disparitet u regionalnom razvoju Hrvatske', ['Depopulation of the county and disparity in regional development of Croatia'] Društvena istraživanja, no 13 (4-5), 2004, pp. 701-726.

Petak, A., Zbirna ocjena stanja u hrvatskom selu, prilog Nacrt nacionalnog programa za poljoprivreredu i seoska područja, sastavnica, Obrazovanje i ljudski potencijali, [Evaluation of the status of the Croatian village, Draft for the national programme for agricultural and rural areas, Education and human potential], Zagreb 2002: AF. Pini, B., 'Agriculture; Farming; Leadership; Culture; Australia; Gender', Women in Management Review, no 17(6), 2002, pp. 276-284.

Pokos, N., Metodologija izdvajanja seoskog stanovnišva, njegov raspored i popisne promjene 1953-2001 [The methodology of separating rural populations, their arrangement and regulation changes 1953-2001], in: M. Štambuk, I. Rogic and A. Mišetić, (eds.), Prostor Iza: Kako modernizacija mijenja hrvatsko selo [The Space Behind: How Modernisation has Changed the Croatian Village Anthology no. 17], Zagreb 2002: Institute of Social Sciences, Ivo Pilar.

Poiner, G., The good old rule: Gender and other power relationships in a rural community, Sydney 1990: Sydney University Press.

Rihtman-Auguštin, D., 'Patrijarhalism danas' ['Patriarchy today'] Žena, no 43(5-6), 1985, pp. 33-43.

Sachs, C.E., The Invisible Farmers: Women in Agricultural Production, Totowa 1983, NJ: Rowman and Allanheld.

Sachs, C. (), Gendered fields. Rural women, agriculture, and environment, Boulder 1996, CO: Westview Press.

Serefagić, D., Selo: izbor ili usud [Village: Choice or fate], Zagreb 2002: Institut za društvena istraživanja. Biblioteka Znanost i društvo.

Share, P., 'Beyond Country Mindedness: Representations in the post-rural era', in: P. Share (ed.), Communications and Culture in Rural Areas, Key Papers, no 4, Wagga Wagga 1995: Centre for Rural Research.

Shortall, S., Women and farming. Property and power, London 1999: Macmillan.

Štambuk, M. and Rogic, I. (eds.), Buducnost na rubu mocvare. Razvojni izgledi naselja na Lonjskom polju, [Future at the edge of the marshland. Developmental perspectives in the settlement of Lonjski Polje], Zagreb 2001: Institute Ivo Pilar. 
Štambuk, M., Rogić, I. and Mišetić, A. (eds.), Prostor Iza: Kako modernizacija mijenja hrvatsko selo [The Space Behind: How Modernisation has Changed the Croatian Village], Zagreb 2002: Institute of Social Sciences, Ivo Pilar.

Štambuk, M., 'Stigmatična personalizacija seljaka' ['Stigmatic Personalisation of Peasants'], Zbornik Pravnog fakulteta Sveučilišta u Rijeci, no 24 (2), 2003, pp. 809-818.

Teather, E.K., 'The Double Bind: Being female and being rural: A comparative study of Australia, New Zealand and Canada', Rural Society, no 8 (3), 1998, pp. 209-221.

Teather, E.K. and M. Franklin, Signposts for rural women in the 1990s, in: M. Franklin, L.M. Short, E.K. Teather (eds) Country women at the crossroads: Perspectives on the lives of rural Australian women in the 1990s, Armidale 1994: University of New England Press.

Tomić-Koludrović, I. and Kunac, S., Žene u procjepu modernizacije hrvatskog društva. Izvješće o provedenom istraživanju: Politički i kulturni aspekti društvenog položaja žena u gradu Zagrebu [Women in a tight spot in the Modernisation of Croatian Society. Research Report: The political and cultural aspects of the social position of women in the city of Zagreb], Women Split 1999: Stop Nade, p. 107.

Tomić-Koludrović, I. and Kunac, S., Rizici modernizacije: žene u Hrvatskoj devedesetih [The risks of Modernisation: Women in Croatia during the nineties], Split 2000: Stop Nade.

Whatmore, S., Farming women: gender, work and family enterprise Houndmills 1991: Macmillan.

Whatmore, S., Theoretical Achievements and Challenges in European Rural Gender Studies; in: M. van der Burg and M. Endeveld (eds.), Women on Family Farms Gender Research, EC Policies and New Perspectives, Wageningen 1994: Circle for Rural European Studies.

Williams, J., The Invisible Farmer. A Report on Australian Farm Women, Commonwealth Department, 1992.

Žutinić, Đ., 'O položaju i ulozi seoske žene u Hrvatskom zagorju' ['The position and role of rural women the Croatian tramontane region'], Gazophylacium, no 3-4, 1994, pp. 306-314.

Žutinic, Đ., Women's role in the revitalization of Croatian rural areas, in: A. Ilak-Peršurić (ed.), Women's perspectives in family farming and rural development, Poreč 2003a: Institute for Agriculture and Tourism,. pp. 83-92.

Žutinic, Đ., 'Obrazovanje i ruralni razvoj' ['Education and Rural Development'], paper presented on Conference "A Partnership for Sustainable Rural Economic Revitalization in Croatia", University of Zagreb, ICAM and University of Georgia, Lošinj, Croatia, 2003 b. 